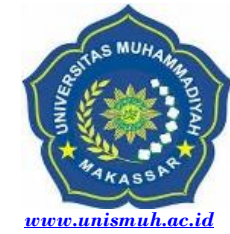

dan Kewarganegaraan

Vol 4 Januari No. 12019

\title{
Analisis Pelaksanaan Pembelajaran PPKn dalam Pembentukan Karakter Siswa SMP
}

\section{Muhammadiyah 1 Makassar}

\author{
Muhajir $^{1)} \&$ Nandri Sugiarti2) \\ Pendidikan Pancasila dan Kewarganegaraan FKIP Universitas Muhammadiyah Makassar ${ }^{1)}$ \\ Pendidikan Pancasila dan Kewarganegaraan FKIP Universitas Muhammadiyah Makassar²) \\ $\underline{\text { muhajir@unismuh.ac.id }}{ }^{1)}$ nandrisugiarti@unismuh.ac.id ${ }^{2}$
}

\begin{abstract}
Pancasila education and citizenship is a planned business and is a continuous process. The large number of shifts in the lives of Indonesian students is currently a very important problem for education in Indonesia. This study aims to: (1) analyze the implementation of PPKn learning in student character formation, and (2) find out the challenges faced by PPKn teachers in forming the character of students of Makassar 1 Muhammadiyah Middle School. This research is a descriptive qualitative study. Data source samples were taken using Purposive sampling technique. Research variables include the implementation of PPKn learning and student character. Data collection techniques using interviews, documentation, and observation. The results of the study indicate that First, the implementation of PPKn learning carried out by the teacher in the class has included character values; Second, the factors that inhibit character formation are students 'lack of understanding of character, lack of PPKn lesson hours, and students' self awareness; Third, how to minimize obstacles, namely to provide understanding and examples to students about character values, increase PPKn lesson hours in schools, and foster awareness in students about the importance of character.
\end{abstract}

Keywords : Learning Implementation, PPKn, Student Character.

\begin{abstract}
Abstrak. Pendidikan Pancasila dan kewarganegaraan adalah usaha terencana dan merupaka proses yang berkesinambungan. Banyaknya pergeseran kehidupan pelajar Indonesia saat ini menjadi sebuah masalah yang sangat penting bagi pendidikan di indonesia. Penelitian ini bertujuan untuk: (1) menganalisis pelaksanaan pembelajaran PPKn dalam pembentukan karakter siswa, dan (2) mengetahui tantangan yang dihadapi guru PPKn dalam pembentukan karakter siswa SMP Muhammadiyah 1 Makassar. Penelitian ini merupakan penelitian kualitatif deskriptif. Sampel sumber data diambil menggunakan teknik Purposive sampling. Variabel penelitian meliputi pelaksanaan pembelajaran PPKn dan karakter siswa. Teknik pengumpulan data menggunakan wawancara, dokumentasi, dan observasi. Hasil penelitian menunjukkan bahwa Pertama, pelaksanaan pembelajaran PPKn yang dilaksanakan oleh guru di kelas sudah memasukkan nilai-nilai karakter; Kedua, faktor-faktor yang menghambat pembentukan karakter adalah tidak pahamnya siswa tentang karakter, kurangnya jam pelajaran PPKn, serta kesadaran diri siswa tersebut; Ketiga, cara meminimalisir kendala yaitu memberikan pemahaman serta contoh kepada siswa tentang nilai-nilai karakter, menambah jam pelajaran PPKn di sekolah, serta menumbuhkan kesadaran dalam diri siswa tentang pentingnya karakter.
\end{abstract}

Kata kunci: Pelaksanaan Pembelajaran, PPKn, Karakter Siswa. 


\section{PENDAHULUAN}

Praktek mengajar PPKn saat ini lebih banyak berlangsung dengan pendekatan konvensional. Selama mengajar, guru lebih banyak mengunakan metode ceramah dan tanya jawab. Siswa Cuma menjadi pendengar di dalam kelas, kemudian menjawab soal. Pembelajaran berlangsung monoton dan guru menjadi satu satunya sumber informasih. Selain itu, mengajar PPKn jarang mengunakan media yang menunjang. Pembelajaran seperti ini jelas amat membosankan.

Pembelajaran tidak kontekstual, materi PPKn sebetulnya banyak yang bisa di ajarkan sesuai realita kehidupan siswa. Tapi, dalam prakteknya, karna telah terbiasa mengajar dengan ceramah, akhirnya semua materi disajikan dalam bentuk ceramah dan tanya jawab. Apa yang diperoleh siswa sekadar apa yang di sampaikan gurunya. Itupun jika terserap semua.

Negara Indonesia merupakan suatu negara yang menaruh perhatian besar pada masalah pendidikan karakter. Kurikulum sekolah mulai dari tingkat paling rendah hingga paling tinggi, mengalokasikan waktu yang cukup banyak bagi bidang studi potensial untuk pembinaan karakter atau akhlak yaitu PPKn.

Namun, pada kenyataannya kebanyakan dari siswa tidak sesuai dengan harapan yang diinginkan. PPKn yang diyakini mampu meminimalisir dan membendung rusaknya moral anak bangsa, saat ini masih ironi, serbab masih ditemukan kesenjangan antara harapan dengan kenyataan yang ada dalam dunia pendidikan. Indonesia sedang dihadapkan pada masalah mentalitas yang terkait dengan masalah karakter seperti sifat yang meremehkan mutu, suka menerabas, tidak percaya diri sendiri, tidak berdisiplin murni, dan suka mengabaikan tanggung jawab.

Sumber dari musibah dan bencana yang telah meluluhkan moralitas bangsa ini adalah terabaikannya pendidikan karakter. Kementrian Pendidikan Nasional mencanangkan gerakan nasional berupa pendidikan karakter, dengan adanya pendidikan karakter tersebut diharapkan mampu menjadi solusi atas rapuhnya karakter bangsa selama ini.
Dewasa ini bangsa Indonesia dilanda krisis moral, tidak hanya pada tataran pimpinan pemerintahan dan birokrat semata, tetapi telah merambah dasar hingga pada anak-anak sekolah. Hal ini bisa dilihat dari tawuran pelajar, kriminal anak-anak remaja, dan sebagainya. Ini menunjukkan bangsa kita telah kehilangan jati diri dan karakternya. Di sisi lain karakter merupakan kualitas perilaku kolektif kebangsaan yang khas baik, yang tercermin dalam kesadaran, pemahaman, rasa, karsa, dan perilaku berbangsa dan bernegara sebagai hasil olah pikir, olah hati, olah rasa dan karsa seseorang atau sekelompok orang berdasarkan nilai-nilai Pancasila, norma, UUD 1945, keberagaman dengan prinsip Bhinneka Tunggal Ika, dan komitmen terhadap NKRI, sehingga pendidikan karakter perlu dimiliki dan ditanamkan kepada siswa.Tujuan dari penelitian ini adalah untuk mengetahui dan membuktikan pengaruh pembelajaran pendidian kewarganegaraan (PKn) terhadap pembentukan karakter siswa.

\section{METODE PENELITIAN}

Jenis penelitian yang digunakan dalam penelitian ini adalah penelitian kualitatif (Non Probability). Metode penelitian kualitatif adalah metode penelitian naturalistik karna penelitiannya dilakukan pada kondisi yang alamiah, disebut juga sebagai metode etnographi, karena pada awalnya motede ini lebih banyak digunakan untuk penelitian bidang antropologi budaya disebut sebagai metode kualitatif, karna data yang terkumpul dan analisisnya lebih bersifat kualitatif. Instrumen penelitian adalah alat yang dipakai untuk memperoleh data, adapun instrumen yang dipakai yaitu:

1. Lembar observasi adalah lembar kerja yang berfungsi untuk mengobservasi dan mengukur tingkat keberhasilan atau ketercapaian tujuan pembelajaran pada kegiatan belajar mengajar dikelas.

2. Lembar wawancara, Wawancara merupakan percakapan antara dua orang atau lebih dan berlangsung antara narasumber dan pewawancara . 
Adapun tekhnik pengumpulan data (a) Observasi. dalam penelitian ini observasi di lakukan dalam beberapa tahapan sebagai berikut observasi sikap dan perilaku warga sekolah dan keadaan lingkungan sekolah dan observasi dalam pembelajaran ppkn. (b) Wawacara. Tehnik wawancara yang digunakan dalam penelitian ini adalah wawancara langsung. Berupa interfiu secara mendalam kepada informan. Percakapan ini dilakukan oleh kedua pihak, yaitu pewawancara yang memberi pertanyaan dan yang diwawancarai memberikan jawaban atas pertanyaan itu. (c) Dokumentasi. Metode ini digunakan untuk mencari dan mengumpulkan data serta informasi tertulis yang berhubungan dengan masalah penelitian. Salah satu dokumen yang diperlukan dalam penelitian ini yaitu RPP Guru.

\section{PEMBAHASAN}

\section{Gambaran Lokasi Umum}

SMP Muhammadiyah 1, disingkat "Spemsa" mulai beropersi tahun 1948 bertempat di Jl. Muhammadiyah No. 52. Pada tahun 1974 sekolah ini dipindahkan ke Jl.Urip Sumoharjo Lr.81/12 menempati tanah wakaf dari Bapak Husain Manuntungi seluas $2100 \mathrm{~m}^{2}$. Sejak tahun 1950-an sekolah ini terkenal dengan nama "SMP Muhammadiya Bersubsidi".Kemudian pada tahun 1985 sekolah ini berubah status menjadi "SMP Muhammadiyah Disamakan". Selanjutnya berubah menjadi SMP Muhammadiyah I Makassar. Seperti yang telah diuraikan sebelumnya bahwa penelitian ini bertujuan untuk menganalisis pelaksanaan pembelajaraan PPKn dalam membentuk karakter SMP Muhammadiyah 1 Makassar. Berdasarkan hasil penelitian yang telah dilaksanakan ditemukan beberapa data yang diharapkan dapat menjawab permasalahan. Berikut adalah pemaparan atau deskripsi hasil wawancara, observasi, dan dokumentasi.

Guna memperoleh gambaran data tentang pelaksanaan pembelajaran PPKn dalam membentuk karakter siswa SMP Muhammadiyah 1 Makassar pada tahun 2018/2019 dara tersebut disajikan sebagai berikut:

\section{Pelaksanaan Pembelajaran PPKn dalam pembentukan karakter siswa Pelaksanaan Pembelajaran PPKn}

Berdasarkan wawancara dengan Dra. Nuraidah selaku guru PPKn kelas VII, dalam memulai pembelajaran guru akan mengucapkan salam, dan siswa menjawabnya, kemudian membaca doa dipimpin oleh ketua kelas. Dalam pengamatan/observasi langsung di kelas VII, peneliti melihat bahwa saat memulai pelajaran guru memperhatikan seluruh siswa, apakah masih ada sudah lengkap atau belum, kemudian meminta seluruh siswa memperhatikan seluruh lingkungan kelas apakah sudah bersih atau belum, bila masih ada sedikit sampah, maka siswa diminta untuk memungut sampah tersebut. Setelah siswa siap dari segi tempat dan kelengkapan, maka guru akan meminta ketua kelas untuk membaca doa sebelum belajar, kemudian mengarahkan siswa untuk membaca Al-quran dengan meminta satu orang untuk memimpin. Setelah selesai semua baru dimulai materi PPKn.

Berdasarkan hasil dokumentasi kelas VII, guru memulai pembelajaran dengan menyampaikan tujuan pembelajaran yang hendak dicapai, kemudian guru memotivasi siswa dengan cara memberikan tanya jawab tentang materi yang ingin dipelajari.

Berdasarkan hasil wawancara dengan Drs. Muh. Anas selaku guru PPKn kelas VIII, beliau mengatakan saat memulai pembelajaran diwajibkan membaca doa, serta penghuni kelas harus dalam keadaan siap untuk menerima pelajaran. Melihat hasil pengamatan langsung di kelas VIII, siswa memulai pelajarn PPKn dengan membaca doa dan mengucapkan salam, kemudian guru mngabsen seluruh siswa, apakah hadir semua atau tidak.

Dari dokumentasi kelas VIII diketahui bahwa pembelajaran PPKn di kelas dimulai dengan: Guru mempersiapkan secara fisik dan psikis peserta didik untuk mengikuti pembelajaran dengan diawali berdoa, menanyakan kehadiran peserta didik, kebersihan dan kerapian kelas, kesiapan buku tulis dan sumber belajar; Guru memberi motivasi dengan membimbing peserta didik memahami nilai-nilai Pancasila sebagai dasar negara dan pandangan hidup bangsa; Guru mengingatkan kembali tentang konsep-konsep yang telah dipelajari oleh peserta didik yang berhubungan dengan materi baru yang akan dipelajari; Guru melakukan apersepsi melalui tanya jawab mengenai nilai-nilai Pancasila sebagai dasar negara 
dan pandangan hidup bangsa; Guru menyampaikan kompetensi dasar dan tujuan pembelajaran yang akan dicapai; Guru membimbing peserta didik melalui tanya jawab tentang manfaat proses pembelajaran; Guru menjelaskan materi dan kegiatan pembelajaran yang akan dilakukan peserta didik.

Berdasarkan data yang diperoleh pada saat peneliti melakukan pengamatan di kelas IX dengan tujuan mengetahui pelaksanaan pembelajaran PKn di kelas, kegiatan guru dalam mengawali pembelajaran adalah pertama guru masuk ke kelas, lalu mengucapkan salam, menanyakan siapa yang piket kebersihan kelas karena kelas terlihat masih kotor, kemudian guru memberitahukan tentang apa yang akan di pelajari hari ini, tujuan pembelajaran yang akan dicapaitetapi masih terbatas tujuan pencapaian materi, belum pada pencapaian karakter.

Berdasarkan dokumentasi kelas IX, kegiatan awal dalam memulai pembelajaran yaitu: Orientasi (Melakukan pembukaan dengan salam pembuka dan berdoa untuk memulai pembelajaran, Memeriksa kehadiran peserta didik sebagai sikap disiplin, Menyiapkan fisik dan psikis peserta didik dalam mengawali kegiatan pembelajaran), Apersepsi (Mengaitkan materi pembelajaran yang akan dilakukan dengan pengalaman peserta didik dengan tema sebelumnya, Mengingatkan kembali materi prasyarat dengan bertanya, Mengajukan pertanyaan yang ada keterkaitannya dengan pelajaran yang akan dilakukan), Motivasi (Memberikan gambaran tentang manfaat mempelajari pelajaran yang akan dipelajari, Menyampaikan tujuan pembelajaran pada pertemuan yang berlangsung, Mengajukan pertanyaan), Pemberian Acuan (Memberitahukan materi pelajaran yang akan dibahas pada pertemuan saat itu, Memberitahukan tentang standar kompetensi, kompetensi dasar, indikator, dan KKM pada pertemuan yang berlangsung, Pembagian kelompok belajar, Menjelaskan mekanisme pelaksanaan pengalaman belajar sesuai dengan langkah-langkah pembelajaran).

Berdasarkan dokumentasi kelas VII, guru menyampaikan materi menggunakan metode ceramah, siswa sebagai penerima materi diharapkan dapat mendengar materi dengan saksama karena metode ceramah sangat mengacu pada pendengaran, apabila siswa tidak memperhatikan penjelasan guru maka akan sulit untuk memahami isi materi tersebut. Di akhir sesi paga kegiatan inti, siswa diminta untuk berdiskusi mengenai materi yang telah diterima.

Saat melakukan pengamatan di kelas VII, guru menggunakan metode ceramah dalam pembelajaran, guru bertindak aktif (pembicara), dan siswa bertindak pasif (pendengar), namun setelah pemberian materi selesai, siswa diminta berperan aktif dengan cara berdiskusi mengenai materi yang telah dijelaskan oleh guru.

Kegiatan inti dimulai dengan mengamati, menanya, mengumpulkan informasi, mengasosiasi, dan mengumpulkan. Sedangkan dalam pengamatan di kelas VIII, peneliti melihat bahwa semua langkah pembelajaran sesuai dengan yang tercantum, dimana kegiatan inti diawali dengan mengamati, menanya, mengumpulkan informasi, mengasosiasi, dan mengomunikasikan.

Berdasarkan dokumentasi kelas IX, kegiatan inti diawali dengan pembentukan kelompok, kemudian setiap kelompok diminta untuk melihat, mengamati, membaca, mendengar, serta menyimak materi yang ingin dipelajari; siswa diminta bertanya tentang materi yang belum dipahami; siswa mengumpulkan materi dari berbagai sumber yang ada (buku); siswa mendiskusikan materi yang dipelajari dengan anggota kelompok masing-masing, siswa mempresentasikan hasil diskusi, dan kelompok yang lain harus membaerikan pertanyaan kepada kelompok yang naik (bertukar informasi); guru menambah keluasan dan kedalaman sampai kepada pengolahan informasi yang bersifat mencari solusi dari berbagai sumber yang memiliki pendapat yang berbeda sampai kepada yang bertentangan untuk mengembangkan sikap jujur, teliti, disiplin, taat aturan, kerja keras, kemampuan menerapkan prosedur dan kemampuan berpikir induktif serta deduktif dalam menyimpulkan; guru menyampaikan hasil diskusi berupa kesimpulan berdasarkan hasil analisis secara lisan, tertulis, atau media lainnya untuk mengembangkan sikap jujur, teliti, toleransi, kemampuan berpikir sistematis, mengungkapkan pendapat dengan sopan; guru bertanya atas presentasi yang dilakukan dan peserta didik lain diberi kesempatan untuk menjawabnya; guru menyimpulkan tentang pointpoint penting yang muncul dalam kegiatan pembelajaran yang baru dilakukan; siswa menjawab pertanyaan yang terdapat pada buku pegangan peserta didik atau lembar kerja yang telah disediakan; siswa bertanya tentang hal yang belum dipahami, atau guru melemparkan beberapa pertanyaan kepada siswa; terakhir siswa 
menyelesaikan uji kompetensi yang terdapat pada buku pegangan peserta didik atau pada lembar kerja yang telah disediakan secara individu untuk mengecek penguasaan siswa terhadap materi pelajaran.

Kemudian pemaparan data yang diperoleh dari observasi dan pengamatan kepada sumber penelitian di SMP Muhammadiyah 1 Makassar tentang kegiatan strategi pembelajaran yang dilakukan guru pada inti pembelajaran, menyatakan bahwa guru di SMP Muhammadiyah 1 Makassar masih melaksanakan pembelajaran yang sangat sederhana yaitu dengan ceramah bervariasi, penugasan, diskusi dan tanya jawab yang bersifat ekspositori sehingga belum menerapkan pembelajaran aktif pada pembelajaran PPKn. Padahal pembelajaran saat ini dituntut agar siswa berperan aktif.

Berdasarkan dokumentasi RPP kelas VII, kegiatan penutup yang dilakukan adalah guru memberi kesempatan kepada peserta didik untuk bertanya bila dirasa belum jelas, guru menyimpulkan hasil penjelasan dengan singkat, peserta didik mencatat simpulan akhir, serta peserta didik mencatat tugas-tugas kegiatan yang diberikan guru.

Sesuai dengan hasil observasi kegiatan penutup di kelas VII, kegiatan penutup diawali dengan guru bertanya kepada peserta didik, tentang materi yang telah dipelajari, serta bertanya apakah sudah paham atau belum; setelah itu guru menyimpulkan materi hari ini, selanjutnya guru memberikan motivasi kepada siswa, dan terakhir membaca doa setelah belajar disertai ucapan salam.

Guru membimbing peserta didik menyimpulkan materi pembelajaran melalui tanya jawab klasikal dan mendorong siswa untuk selalu bersyukur atas karunia Tuhan, guru melakukan refleksi dengan peserta didik atas manfaat proses pembelajaran yang telah dilakukan, guru memberikan umpan balik atas proses pembelajaran dan hasil telaah individu maupun kelompok, guru melakukan tes tertulis dengan menggunakan Uji Kompetensi atau soal yang disusun guru sesuai tujuan pembelajaran, guru dapat meminta peserta didik untuk meningkatkan pemahamannya tentang konsep, prinsip atau teori yang telah dipelajari dari buku-buku pelajaran yang relevan atau sumber informasi lainnya, guru merencanakan kegiatan tindak lanjut dalam bentuk pembelajaran remidi, program pengayaan, layanan konseling dan/atau memberikan tugas baik tugas individual maupun kelompok sesuai dengan hasil belajar peserta didik, guru menyampaikan rencana pembelajaran pada pertemuan berikutnya.

Berbeda dengan hasil observasi yang dilakukan di kelas VIII, kegiatan penutup yang dilakukan adalah: guru memotivasi siswa, memberikan kesimpulkan tentang materi, namun dalam pelaksanaannya sesi akhir penutup dilaksanakan dengan membaca doa setelah belajar dan ucapan salam.

Berdasarkan dokumentasi kelas IX, langkah kegiatan penutup yang dilaksankan adalah: peeserta didik (membuat resume dengan bimbingan guru tentang point-point penting yang muncul dalam kegiatan pembelajaran yang baru dilakukan, mengagendakan pekerjaan rumah, mengagendakan materi yang harus dipelajari pada pertemuan berikutnya di luar jam sekolah atau dirumah), guru (memeriksa pekerjaan siswa yang selesai langsung diperiksa, peserta didik yang selesai mengerjakan soal dengan benar diberi paraf serta diberi nomor urut peringkat, untuk penilaian portofolio, memberikan penghargaan kepada kelompok yang memiliki kinerja dan kerjasama yang baik).

Sejalan dengan yang dilakukan sesuai di kelas IX yaitu: guru meminta peserta didik membuat ringkasan tentang materi yang telah dipelajari, memberi pekerjaan rumah kepada siswa berupa soal (kerja dulu di sekolah, bila sudah selesai guru langsung memeriksa, bila belum dibawa ke rumah), guru memberi materi inti (materi selanjutnya), membaca doa sesudah pelajaran dan diiringi ucapan salam.

\section{Dokumen perencanaan pembelajaran (RPP).}

Data dokumentasi perencanaan pembelajaran yang diperoleh peneliti adalah silabus dan RPP. Berdasarkan dokumentasi yang di peroleh di SMP Muhammadiyah 1 Makassar, dalam silabus kelas VII tertulis beberapa nilai karakter yang akan dikembangkan dalam pembelajaran PPKn. Nilai karakter tersebut antara lain; dapat dipercaya, tekun, rasa hormat, perhatian, tanggung jawab, nilai karakter tekun, tanggung jawab, kepedulian lingkungan, disiplin, dan kewarganegaraan. Kemudian dalam silabus kelas VIII tertulis antara lain; berpikir strategis, kritis, bertanggung jawab, dapat dipercaya, berani, ketulusan, integritas, peduli, kewarganegaraan, dan nasionalisme. Sedangkan dalam RPP tertulis nilai karakter yang akan dikembangkan dalam pembelajaran anta lain; sera pada RPP kelas IX 
jujur, disiplin, tanggungjawab, peduli (toleransi, gotong royong), santun, percaya diri.

\section{Media Pembelajaran}

Dalam penelitian yang dilakukan di SMP Muhammadiyah 1 Makassar, menurut Dra. Nuraidah dalam wawancara, media yang sering digunakan adalah lembar kerja siswa, lembar penilaian, LCD atau proyektor namun kadang menyesuaikan materi yang diajarkan, serta mengaitkannya dengan materi pelajaran yang sedang dipelajari. Untuk materi yang sedang dipelajari ini guru menggunakan media gambar, dari koran, majalah atau gambar apa saja yang berhubungan dengan materi. Dalam RPP, diketahui bahwa media yang digunakan oleh guru dalam pelaksanaan pembelajaran adalah gambar-gambar.

Kemudian dalam pengamatan saat beliau mengajar di kelas diketahui bahwa media yang digunakan oleh guru pada saat pelaksanaan pembelajaran berlangsung adalah white board, dan potongan-potongan gambar. Berdasarkan beberapa data yang didapat dari wawancara, dokumentasi, dan pengamatan diatas, dapat diketahui bahwa guru memang menggunakan media white board, dan gambar-gambar dan telah melaksanakan pembelajaran menggunakan media yang sesuai dengan RPP. Dalam akhir pembelajaran beliau juga membagikan lembar kerja siswa serta lembar penilaian untuk mengukur hasil belajar siswa.

Berdasarkan data pengamatan di kelas VIII Abdi Awiruddin, S. Pd. Selaku guru PPKn hanya menggunakan papan tulis dan alat tulisnya. Dan berdasarkan data yang diperoleh melalui dokumentasi dan observasi/pengamatan kepada sumber diatas diketahui bahwa beliau masih menggunakan media pembelajaran yang sangat sederhana yaitu papan tulis. Dalam wawancara beliau mengatakan bahwa media yang digunakan adalah gambar-gambar (rang demo), namun saat observasi kelas, peneliti tidak melihat adanya gambar, beliau hanya menggunakan papan tulis sebagai media.

Sesuai dokumentasi kelas VIII, media yang digunakan adalah power point (LCD), namun bertolak belakang dengan pelaksanaan pembelajaran, karena beliau tidak menggunakan LCD melainkan hanya papan tulis. Berdasarkan pengamatan di sekolah, sarana prasarana cukup lengkap, sekolah juga sudah mempunya proyektor (LCD) sendiri.

Sesuai dokumentasi kelas IX, media pembelajaran yang dipakai tidak dicantumkan.
Dilihat dari observasi langsung, media yang digunakan adalah papan tulis dan gambar-gambar yang berhubungan dengan materi.

\section{Evaluasi Pembentukan Karakter dalam Pelaksanaan Pembelajaran PPKn}

Dalam mengevaluasi pendidikan karakter siswa kelas VII, menurut Dra. Nuraidah beliau menggunakan angket (instrumen penilaian sikap), setiap siswa akan dilihat bagaimana karakternya dalam belajar terutama PPKn, angket tersebut digunakan untuk melihat sikap baik dan buruk siswa. Melihat dokumentasi kelas VII, tidak ada tercantum tentang penilaian sikap, yang ada hanya daftar penilaian kognitif dan psikomotorik, hal ini tentu berbeda dengan hasil wawancara yang dilakukan. Sedangkan, saat peneliti melakukan pengamatan langsung di kelas VII, penilaian sikap yang dilakukan guru yaitu dengan cara mengisi daftar instrumen penilaian sikap, setiap siswa dinilai secara pribadi oleh guru, apabila siswa ribut maka akan dicatat, begitu pula sebaliknya apabila ada siswa yang berbuat baik akan mendapat penilaian tersendiri dari guru.

Dalam menilai pendidikan karakter siswa kelas VIII, menurut Drs. Muh. Anas beliau melakukan evaluasi, namun cara yang digunakan tidak beliau jelaskan secara detail. Berdasarkan dokumentasi kelas VIII, penilaian karakter siswa dinilai menggunakan instrumen penilaian sikap, instrumen yang digunakan sangat detail dan jelas. Saat peneliti melakukan observasi langsung guru melakukan penilaian sikap dengan langkah sebagai berikut : setiap siswa dinilai sikap tanggung jawab, disiplin, kerja keras, kreatif, rasa ingin tahu, dan tanggung jawab dalam dirinya. Guru secara langsung menilai siswa dengan memberi skor pada setiap indikator sikap yang ingin dicapai.

Sehingga berdasarkan pemaparan data yang diperoleh dari wawancara, observasi dan pengamatan kepada sumber penelitian di SMP Muhammadiyah 1 Makassar tentang evaluasi yang dilakukan oleh guru dalam pelaksanaan pembelajaran PPKn, dapat diketahui bahwa guru di SMP Muhammadiyah 1 Makassar sudah melakukan evaluasi yang berarti pada aspek nilai-nilai karakter siswa dalam pelaksanaan pembelajaran. Meskipun belum efektif, setidaknya sudah ada penilaian karakter yang terdapat dalam pelaksanaan pembelajaran PPKn.

Tantangan yang dihadapi guru PPKn dalam pembentukan karakter siswa

Berdasarkan wawancara yang telah dilakukan, menurut Dra. Nuraidah kesulitan dalam 
membentuk karakter siswa terjadi apabila ada siswa yang belum tahu menulis dengan baik, siswa tersebut sangat sulit dibentuk karena nilai dasar dari karakter itu sendiri ia tak tahu, apalagi ingin membentuk dan menanamkan karakter dalam dirinya. Siswa yang demikian harus dibentuk secara khusus, guru harus mempunyai perhatian yang terfokus pada dirinya. Jam pelajaran yang sedikit membuat pembentukan karakter melalui pelaksanaan pembelajaran PPKn tidak terlaksana dengan baik, namun sejak berlakunya Kurikulum K13, pelaksanaan pembelajaran PPKn dalam membentuk karakter sudah terlaksana dengan baik, karena jam pelajaran yang dulunya hanya 2 jam pelajaran kini berubah menjadi 3 jam pelajaran. Guru yang sibuk mungkin dapat mengganggu pembentukan karakter, namun menurut beliau secara pribadi, tidak ada hambatan dan masalah yang berarti dalam pembentukan karakter siswa di SMP Muhammadiyah 1 Makassar karena beliau fokus mengajar di sekolah tersebut, tidak mengajar di sekolah lain.

Menurut Drs. Muh. Anas kesulitan dalam pembentukan karakter berasal dari pribadi siswa, terkadang ada siswa yang pribadinya sulit diatur, sehingga penanaman karakter sulit dilakukan. Ada beberapa penghambat dalam pembentukan karakter, misalnya kurangnya jam belajar PPKn (bukan faktor utama), adapun faktor utama yaitu kesadaran dalam diri siswa itu sendiri, bagi beliau sekeras apapun guru mencoba apabila kesadran dalam diri siswa itu kurang maka hasilnyapun akan kurang. Sedangkan, kesibukan guru tidak menjadi faktor dalam menghambat pembentukan karakter siswa.

Berdasarkan hasil wawancara, dapat disimpulkan bahwa faktor-faktor yang menghambat pembentukan karakter adalah tidak pahamnya siswa tentang karakter, kurangnya jam pelajaran PPKn (sebagai mata pelajaran pembentuk karakter), serta kesadaran diri siswa tersebut.

\section{Tidak pahamnya siswa tentang karakter}

Kurangnya pemahaman siswa tentang karakter membuat penanaman karakter menjadi sulit, meskipun demikian cara terbaik agar siswa tahu tentang karakter yaitu dengan menjadikan guru sebagai panutan. Guru yang menjadi panutan harus guru yang benar-benar memiliki etika yang baik. Guru-guru yang memenuhi syaratlah yang menjadi role model utama bagi siwa. Mereka punya kesempatan untuk membentuk karakter siswa, misalnya, dengan melaksanakan saling menghargai dan pertanggung jawab dalam proses pembelajaran. Namun guru-guru pun dalam pembelajaran dan kesehariannya harus mengejar kurikulum dan berorientasi kepada tes ketimbang pengembangan karakter siswa.

\section{Kurangnya jam pembelajaran PPKn}

Kurangnya jam pelajaran PPKn memberi dampak dalam penanaman karakter, setiap guru mata pelajaran memang mempunyai kewajiban mengarahkan karakter siswa, namun apabila karakter siswa buruk, guru PPKn dan Agamalah yang disalahkan, hal ini tentu sangat tidak adil. Salah satu solusi agar karakter siswa dapat diterapkan dengan baik yaitu dengan menambah jam pelajaran PPKn yang dirasa kurang.

\section{Rendahnya kesadaran diri siwa}

Banyak siswa yang tahu arti dari karakter, namun tidak bisa menanamkan nilai-nilai yang terkandung di dalamnya, hal ini disebabkan karena banyak siswa yang kesadaran dirinya kurang. Solusi yang dapat diberikan yaitu dengan cara memotivasi siswa agar terus melakukan hal yang terbaik dalam belajar. Member arahan tentang pentingnya menanamkan karakter sejak dini.

\section{Pembahasan}

Pembahasan penelitian terfokus pada pelaksanaan pembelajaran PPKn dalam membentuk karakter siswa, serta kendala yang dihadapi dalam membentuk karakter siswa SMP Muhammadiyah 1 Makassar.

Berdasarkan kajian secara filosofis, sosiologis, yuridis, dan pedagogis, mata pelajaran PPKn dalam Kurikulum 2013, secara utuh memiliki karakteristik sebagai berikut.

1. Nama mata pelajaran yang semula Pendidikan Kewarganegaraan (PKn) telah diubah menjadi Pendidikan Pancasila dan Kewarganegaraan (PPKn);

2. Mata pelajaran PPKn berfungsi sebagai mata pelajaran yang memiliki misi pengokohan kebangsaan dan penggerak pendidikan karakter;

3. Kompetensi Dasar (KD) PPKn dalam bingkai kompetensi inti (KI) yang secara psikologispedagogis menjadi pengintegrasi kompetensi peserta didik secara utuh dan koheren dengan penanaman, pengembangan, dan/atau penguatan nilai dan moral Pancasila; nilai dan norma UUD Negara Republik Indonesia Tahun 1945; nilai dan semangat Bhinneka Tunggal lka; serta wawasan dan komitmen Negara Kesatuan Republik Indonesia.

4. Pendekatan pembelajaran berbasis proses keilmuan (scientific approach) yang dipersyaratkan dalam kurilukum 2013 
memusatkan perhatian pada proses pembangunan pengetahuan (KI-3), keterampilan $(\mathrm{KI}-4)$, sikap spiritual (KI-1) dan sikap sosial (KI2) melalui transformasi pengalaman empirik dan pemaknaan konseptual.

5. Model pembelajaran dikembangkan sesuai dengan karakteristik PPKn secara holistik/utuh dalam rangka peningkatan kualitas belajar dan pembelajaran yang berorientasi pada pengembangan karakter peserta didik sebagai warganegara yang cerdas dan baik secara utuh dalam proses pembelajaran otentik (authentic instructional and authentic learning) dalam bingkai integrasi Kompetensi Inti sikap, pengetahuan, dan keterampilan. Serta model pembelajaran yang mengarahkan peserta didik bersikap dan berpikir ilmiah (scientific) yaitu pembelajaran yang mendorong dan menginspirasi peserta didik berpikir secara kritis, analitis, dan tepat dalam mengidentifikasi, memahami, memecahkan masalah, dan mengaplikasikan materi pembelajaran.

6. Model Penilaian proses pembelajaran dan hasil belajar PPKn menggunakan penilaian otentik (authentic assesment). Penilaian otentik mampu menggambarkan peningkatan hasil belajar peserta didik, baik dalam rangka mengobservasi, menalar, mencoba, membangun jejaring, dan lain-lain. Penilaian otentik cenderung fokus pada tugas-tugas kompleks atau kontekstual, memungkinkan peserta didik untuk menunjukkan kompetensi mereka dalam pengaturan yang lebih otentik.

7. Berdasarkan penelitian yang telah dilakukan, pelaksanaan Kegiatan pembelajaran bertujuan menjadikan peserta didik menguasai kompetensi (materi) yang ditargetkan. Serta dirancang untuk menjadikan peserta didik mengenal, menyadari atau peduli, dan menginternalisasi nilai-nilai dalam bentuk perilaku (Jamal Ma'mur Asmani, 2012:59). Dalam struktur kurikulum kita, ada dua mata pelajaran yang terkait langsung dengan pengembangan budi pekerti dan akhlak mulia, yaitu pendidikan Agama dan PPKn (Sri Narwanti, 2002: 83-85). Namun dalam penelitian ini peneliti hanya membahas mengenai pembelajaran pendidikan karakter pada mata pelajaran PPKn. Nilai-nilai utama yang ada dalam mata pelajaran PPKn antara lain: nasionalis, patuh pada aturan sosial, demokratis, jujur, menghargai keragaman, sadar akan hak dan kewajiban diri dan orang lain.
Nilai-nilai karakter utama yang harus dikembangkan dalam pembelajaran PPKn yaitu nasionalis, patuh pada aturan sosial, demokratis, jujur, menghargai keragaman, sadar akan hak dan kewajiban diri dan orang lain serta nilai-nilai karakter yang lain. Menurut data dokumentasi, materi yang diajarkan dalam PKn telah memuat nilai-nilai karakter antara lain: nilai karakter kewarganegaraan, menghargai orang lain dan nilai karakter yang lainnya dari materi yang membahas tentang demokrasi, kedaulatan rakyat, kemerdekaan mengemukakan pendapat dan Hak Asasi Manusia. Dan melalui observasi, diperoleh data tentang pembelajaran bahwa pelajaran PPKn telah memuat nilai-nilai karakter seperti relgius, displin, cinta ilmu, kerja keras, menghargai orang lain, dan bersikap kritis, kreatif, inovatif. Dalam manajemen pendidikan, proses pembelajaran terdiri dari proses perencanaan, pelaksanaan dan evaluasi.

Dalam pelaksanaan pembelajaran PPKn sudah menerapkan nilai-nilai karakter, meskipun belum terlalu efektif. Dalam pelaksanaannya guru selalu menanamkan nilai karakter baik, seperti memberikan motivasi di akhir pembelajaran, melarang melakukan hal yang buruk. Motivasi yang diberikan guru juga selalu mengarah pada karakter dan akhlaq mulia.

Kegiatan evaluasi oleh guru sudah mengacu pada nilai-nilai karakter, meskipun ada guru yang tidak mencantumkan penilaian sikap (karakter) saat dokumentasi namun dalam pelaksanaannya guru memberikan evaluasi yang berbasis karakter.

Pendidikan karakter yang dilakukan guru secara jelas dilaksanakan dalam pembelajaran dikelas dijumpai peneliti, pelaksanaan pembelajaran (pendahuluan, kegiatan inti, dan penutup), serta evaluasi pelaksanaan pembelajaran terdapat nilia-nilai karakter di dalamnya. Berdasarkan hasil wawancara, dapat disimpulkan bahwa faktor-faktor yang menghambat pembentukan karakter adalah tidak pahamnya siswa tentang karakter, kurangnya jam pelajaran PPKn (sebagai mata pelajaran pembentuk karakter), serta kesadaran diri siswa tersebut.

Siswa yang tidak mempunyai pemahaman akan karakter, akan sulit membentuk karakter dalam dirinya. Cara terbaik agar siswa tersebut paham tentang karakter yaitu dengan memberikan penjelasan padanya apa itu karakter serta memberi contoh yang baik tentang karakter itu sendiri.

Sedikitnya jam pelajaran PPKn sebagai mata pelajaran pembentuk karakter sangat berpengaruh 
terhadap pembentukan karakter itu sendiri. Sebagai pembentuk karakter seharusnya waktu pelajaran PPKn ditambah.

Rendahnya kesadaran dalam diri siswa menjadi faktor penghambat utama pembentukan karakter siswa, untuk menambah kesadaran dalam diri siswa guru harus senantiasa memberi dorongan dan motivasi agar kesadaran dalam diri siswa tentang pentingnnya karakter meningkat.

\section{KESIMPULAN}

Berdasarkan hasil penelitian dan pembahasan disimpulkan bahwa: Pertama, pelaksanaan pembelajaran PPKn yang dilaksanakan oleh guru di kelas sudah memasukkan nilai-nilai karakter. Dilihat dari proses pembelajaran dan wawancara, PPKn adalah mata pelajaran inti dalam menanamkan karakter siswa, setelah diteliti,nilainilai karakter yang ditanamkan dalam proses pembelajaran PPKn sudah cukup baik, meskipun masih belum efektif; Kedua, tantangan yang dihadapi guru PPKn dalam pembentukan karakter adalah tidak pahamnya siswa tentang karakter, kurangnya jam pelajaran PPKn (sebagai mata pelajaran pembentuk karakter), serta kesadaran diri siswa tersebut; Ketiga, untuk meminimalisir kendala yang ada dalam pembentukan karakter yaitu memberikan pemahaman serta contoh kepada siswa tentang nilai-nilai karakter, menambah jam pelajaran PPKn di sekolah, serta menumbuhkan kesadaran dalam diri siswa tentang pentingnya karakter.

\section{DAFTAR PUSTAKA}

[1] Cholisin. (2011). Pengembangan Karakter dalam Materi Pembelajaran PKn (Disampaikan pada kegiatan MGMP PKn SMP Kota Yogyakarta, 18 Januari 2011).

[2] Fajar, Arnie. (2005). Portofolio Dalam Pembelajaran IPS. Bandung : PT. Remaja Rosdakarya.

[3] Frye, Mike, at.all.(Ed) (2002). Character Education: Information Handbook and Guide for Suppor and Implementation of the Student Citizent Act of 2001 North Carolina: Public Schools of North Carolina.

[4] Jamal Ma'mur Asmani. (2012). Buku Panduan Internalisasi Pendidikan Karakter di Sekolah. Yogyakarta: DIVA Press.

[5] Koesoema, Doni A. (2012). Pendidikan Karakter Utuh dan Menyeluruh.Yogyakarta : KANISIUS.
[6] Lickona, Thomas. (1991). Educating for Character: How Our School Can Teach Resect and Resonsibility. New Your, Toronto, Londo, Sydney, Auckland: Bantam Books.

[7] Moleong. (2007). Metodologi Penelitian kualitatif. Bandung: Rosdakarya.

[8] Pasal 39 Undang-Undang No 2 Tahun (1989) Tentang Sistem Pendidikan Nasional.

[9] Pemerintah Republik Indonesia. (2010). Kebijakan Nasional Pembangunan Karakter Bangsa Tahun 2010-2025. Jakarta: Pusat Kurikulum Balitbang Kemdiknas.

[10] Permendiknas No. 22 Tahun (2006). Tentang Standar Isi Untuk Satuan Pendidikan Dasar dan Menengah.

[11] Ryan, Kevin dan Karen E. Bohlin. (1999). Building Character in Schools: Practical Ways to Bring Moral Instruction to Life. San Francisco: ossey Bass.

[12] Soemantri Nurman M. (2001). Menggagas Pembaharuan Pendidikan IPS. Bandung: PT. Remaja Rosdakarya.

[13] Sri Narwanti. (2002). Pendidikan Karakter: Pengimtegrasian 18 Nilai Pembentuk Karakter Dalam Mata Pelajaran. Familia Grup Relasi Inti Media.

[14] Sugiyono. (2014). Metode Penelitian Kuantitatif, Kualitatif, dan $R \& D$. Bandung: Alfabeta.

[15] Suardi, S. (2018). Penerapan Model Pembelajaran Saintifik Approacd Berbasis Media Pembelajaran Kearifan Lokal pada Mata Kuliah Dasar-Dasar Sosiologi dalam Membangun Karakter dan Meningkatkan Hasil Belajar Mahasiswa Pendidikan Sosiologi Universitas Muhammadiyah Makassar. Jurnal Etika Demokrasi Prodi PPKn Unismuh Makassar, 3(2).

[16] Suardi, S. (2018). Penerapan Model Pembelajaran Saintifik Approacd Berbasis Media Pembelajaran Kearifan Lokal pada Mata Kuliah Dasar-Dasar Sosiologi dalam Membangun Karakter dan Meningkatkan Hasil Belajar Mahasiswa Pendidikan Sosiologi Universitas Muhammadiyah Makassar. Jurnal Etika Demokrasi Prodi PPKn Unismuh Makassar, 3(2).

[17] Suardi, S., \& Kanji, H. (2018). Lecture Model of Student Transfer Discussion Method to Increase Student's Activeness and Learning Outcomes. Journal of Educational Science and Technology (EST), 4(1), 48-54

[18] Suardi, S., Megawati, M., \& Kanji, H. (2018). Pendidikan Karakter di Sekolah (Studi Penyimpangan Siswa di MTs Muhammadiyah Tallo) Jurnal Etika Demokrasi Prodi PPKn Unismuh Makassar, 4(1).

[19] Winataputra dan Budimansyah. (2007). civic education. Bandung: Program Pasca sarjana UPI

[20] Winataputra dan Budimansyah. (2012). Pendidikan Perspektif Internasional. Bandung: Widya Aksara Press. 
[21] Winataputra, Udin S. dkk. (2008). Teori Belajar dan Pembelajaran. Jakarta : Universitas Terbuka. 